\title{
Gambaran Polimorfisme Gen Matriks Metalloproteinase-12 (Mpp-12) Pada Penyakit Paru Obstruktif Kronik
}

\author{
Ruth A. K. Sihombing, ${ }^{1}$ Yahwardiah Siregar, ${ }^{2}$ Karolina Br Surbakti, ${ }^{3}$ \\ Biomedik FK USU,Poltekkes Kemenkes Medan \\ Email:sihombingrak@gmail.com
}

\begin{abstract}
Chronic Obstructive Pulmonary Disease (COPD) is a disease characterized by irreversible restriction of airflow in the lungs. Chronic smoking is a major risk factor for developing COPD, but actually only a small proportion of smokers develop airway obstruction. One of the genes that is the main factor causing COPD is the Metalloproteinase12 matrix gene, MMP plays a major role in tissue remodeling and repair, as significant evidence that the MMP group also plays an important role in the pathogenesis of COPD. The aim of this study was to examine genetic variations in the MMP-12 gene. The MMP-12 gene was identified using PCR-RFLP. The results showed that the MMP-12 gene variant was the homozygote AA genotype: 137 bp totaling 28 people (93.33\%) and Heterozygot AG: 137 bp and 119 bp amounted to 2 people (6.67\%). GG genotype variant was not found in this study.
\end{abstract}

Keywords: MMP-12 gene, polymorphism, COPD

\begin{abstract}
ABSTRAK
Penyakit Paru Obstruktif Kronik (PPOK) adalah penyakit yang ditandai dengan terbatasnya aliran udara di paruparu dengan cara ireversibel. Perokok kronis merupakan faktor resiko utama berkembangya PPOK, tetapi sebenarnya hanya sebagian kecil perokok yang berkembang menjadi obstruksi jalan nafas. Salah satu gen yang merupakan faktor utama penyebab PPOK adalah gen Matriks Metalloproteinase-12, MMP berperan utama dalam remodeling dan perbaikan jaringan, sebagai bukti yang signifikan bahwa kelompok MMP juga berperan penting dalam patogenesis PPOK.Tujuan penelitain ini untuk melihat variasi genetic gen MMP-12 pada penderita PPOK yang berjumlah 30 orang.Identifikasi gen MMP-12 menggunakan PCR-RFLP.Hasil penelitian menunjukkan varian gen MMP-12 adalah genotip homozygote AA: 137 bp sebanyak 28 orang (93,33\%) dan Heterozygot AG: 137 bp dan 119 bp berjumlah 2 orang $(6,67 \%)$.Varian genotip GG tidak ditemukan dalam penelitian ini.
\end{abstract}

Kata Kunci: Gen MMP-12, polimorfisme, PPOK.

\section{PENDAHULUAN}

\section{Latar Belakang}

Penyakit Paru Obstruktif Kronik (PPOK) adalah penyakit yang ditandai dengan terbatasnya aliran udara di paru-paru dengan cara ireversibel Walaupun PPOK saat ini adalah beban terbesar ke-12 di seluruh dunia, tetapi diperkirakan hal ini akan terus meningkat hingga menjadi terbesar ke-5 di dunia pada tahun 2020 (1). Pada PPOK, bronkitis kronik dan emfisema sering ditemukan bersama, meskipun keduanya memiliki proses yang berbeda ${ }^{(2)}$

Di Indonesia tidak ada data yang akurat tentang kekerapan PPOK. Berdasarkan studi morbiditas dalam SUSENAS (2005) proporsi penderita PPOK sebesar $10 \%$ dan menduduki peringkat ke-2 sebagai penyebab kematian di Indonesia (PMR 26,4\%) - Berdasarkan studi mortalitas dalam SUSENAS (2005), proporsi penderita PPOK sebesar $7,38 \%$ dan menduduki peringkat ke-4 sebagai penyebab kematian di Indonesia (CFR 3,21\%) ${ }^{(3)}$

Perokok kronis merupakan faktor resiko utama berkembangya PPOK, tetapi sebenarnya hanya sebagian kecil perokok yang berkembang menjadi obstruksi jalan nafas. Faktor genetik berhubungan dengan kerentanan, termasuk gen yang mengatur protease-antiprotease dan interaksi oksidan-antioksidan ${ }^{(1)}$ Salah satu gen yang merupakan faktor utama penyebab PPOK adalah gen Matriks Metalloproteinase-12(MMP-12).

Matriks metaloproteinase (MMP) adalah famili dari enzim endopeptidase yang mewakili kelas utama dari enzim yang bertanggungjawab untuk mendegradasi Extracellular Matrix (ECM). MMP secara bersamasama dapat mendegradasi semua protein matriks ekstraselular. Semua anggotanya disekresikan sebagai proenzim tidak aktif (zimogen) dan diperkirakan akan 
aktif dalam jaringan dengan pembelahan dari propeptida tersebut. Semua MMP mengandung $\mathrm{Zn}^{2+}$ pada sisi katalitik, disamping itu memerlukan $\mathrm{Ca}^{2+}$ untuk aktivitas dan stabilitasnya ${ }^{(4)}$.

MMP berperan utama dalam remodeling dan perbaikan jaringan, sebagai bukti yang signifikan bahwa kelompok MMP juga berperan penting dalam patogenesis PPOK. Tikus knock out yang mengekspresikan MMP-12 terlindung dari emfisema meskipun terpapar asap rokok. MMP-12 sebagai penentu dari bentuk emfisema pada pasien PPOK. Berbagai penelitian melibatkan MMP dalam patogenesis penyakit yang melaporkan asosiasi varian genetik pada MMP-1,9 dan 12 dengan PPOK atau fenotip yang terkait (5).

Polimorfisme promoter MMP-12 (-82A/G) akan meningkatkan ekspresi yang berhubungan dengan peningkatan stenosis arteri koroner pada pasien diabetes. Polimorfisme ini umumnya diidentifikasi dalam promotor gen MMP-12 (substitusi adenosin [A] - untuk - guanosin [G] pada posisi -82) yang mempengaruhi ikatan dari transkripsi protein-1 aktivator (AP-1). Afinitas ikatan dari AP-1 untuk alel A dengan aktivitas in vitro promoter MMP-12 ${ }^{(6)}$.

\section{Tujuan Penelitian}

Tujuan Penelitian ini untuk mengetahui gambaran variasi genetic gen Matriks metalloproteinase-12 ( MMP-12) pada penyakit Penyakit Paru Obstruktif Kronik (PPOK)

\section{METODE PENELITIAN}

\section{Populasi Penelitian}

Desain penelitian ini adalah deskriptif dengan menggunakan desain Cross Sectional. Penelitian dilaksanakan mulai April 2015 sampai Juli 2016. Populasi penelitian adalah penderita PPOK.

Sampel penelitian berasal dari DNA yang telah diisolasi dan merupakan data sekunder dari penderita PPOK dalam bentuk isolat DNA sebesar 30 sampel.Amplifikasi DNA dan digesti enzim restriksi dilaksanakan di Laboratorium Terpadu Fakultas Kedokteran Universitas Sumatera Utara

Kriteria Inklusi pada penelitian adalah :

1. Penderita PPOK yang sudah dipastikan dengan hasil pemeriksaan spirometri : $\mathrm{VEP}_{1} / \mathrm{KVP} \leq 70 \%, 15$ menit setelah diberikan Salbutamol Inhaler dosis terukur dua semprot dengan alat bantu (spacer), derajat menurut GOLD : ringan sampai sangat berat.
2. Umur penderita $\geq 40$ tahun
3. Laki-laki
4. Perokok aktif atau mantan perokok dengan riwayat merokok $\geq 200$ Indeks Brinkman

5. Bersedia mengikuti prosedur penelitian dan diambil sampel darahnya, dinyatakan secara tertulis setelah mendapatkan penjelasan mengenai penelitian.

Kriteria Eksklusi :

1. Penderita penyakit paru seperti TB, Bronkitis kronik atau penyakit paru lain.

2. Keadaan umum penderita dalam keadaan lemah (kaheksia)

3. Terdapat kesulitan dalam pengambilan darah

4. Mempunyai keluarga yang berpenyakit PPOK

\section{Cara kerja}

1. Amplifikasi isolat DNA dengan Polymerase Chain Reaction menggunakan Primer forward MMP-12: 5'GTCAAGGGATGATATCAGCT3'

Primer reverse MMP-12: 5'CTTCTAAACGGATCAATTCAG-3'

2. MMP-12 pada DNA sampel diamplifikasi dengan menggunakan mesin PCR (Thermal Cycler) dengan suhu pre-denaturasi $95^{\circ} \mathrm{C}$ selama 5 menit, diikuti 28 siklus denaturasi pada suhu $94^{\circ} \mathrm{C}$ selama 45 detik, annealing pada suhu $53^{\circ} \mathrm{C}$ selama 30 detik, dan elongasi pada suhu $72^{\circ} \mathrm{C}$ selama 45 detik, dan tahap akhir pada suhu $72^{\circ} \mathrm{C}$ selama 10 menit. ) ${ }^{(7)}$

3. Hasil elektroforesis pada agarose $2 \%$ akan terlihat fragmen DNA sebesar $137 \mathrm{bp}$ ) ${ }^{(7)}$

4. Produk PCR yang didapat sebesar 137bp. Kemudian dipotong oleh enzim Restriksi $P v u I I$ (Thermo scientific $($ )

5. Lakukan reaksi RFLP (Restriction Fragment Length Polymorphism) dengan total volum $10 \mu 1$ untuk setiap sampel yang terdiri dari $2,5 \mu 1$ produk

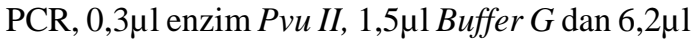
nuclease free water

6. Inkubasi selam 1 jam pada suhu $37^{\circ} \mathrm{C}$ didalam incubator

7. Dilakukan elektroforesis pada agarose $2 \%$ maka akan terlihat 1 band pada homozigot AA (130bp), 2 band pada heterozigot AG (137bp dan 119bp) (7)

\section{HASIL}

Klasifikasi polimorfisme gen MMP-12 dibagi menjadi 3 varian, yaitu, AA, AG, dan GG, Berdasarkan tabel 1, varian gen MMP-12 pada 30 sampel pasien PPOK, adalah genotip homozygote AA: 137 bp sebanyak 28 orang $(93,33 \%)$ dan 
Heterozygot AG: 137 bp dan 119 bp berjumlah 2 orang $(6,67 \%)$.Varian genotip GG tidak ditemukan dalam penelitian ini.

Tabel 1 Data varian gen MMP-12 pada pasien PPOK ( $n=30)$

\begin{tabular}{lccc}
\hline \multicolumn{4}{c}{ GENOTIP MMP-12 } \\
\hline \multirow{2}{*}{ PPOK } & AA(\%) & AG(\%) & GG(\%) \\
& $28(93.33 \%)$ & $2(6.67 \%)$ & $0(0 \%)$ \\
\hline Total & & & $30(100 \%)$ \\
\hline
\end{tabular}

Gambar 1 Produk PCR gen MMP-12 yang dianalisa elektroforesis agarosa $2 \%$ berada pada 137 pasang basa (bp) 
scientific $($ ) analisa elektroforesis agarosa 4\% sampel P19, P20, P21, P26, N9, N10 terlihat $137 \mathrm{bp}$ dan 119bp (RFLP)

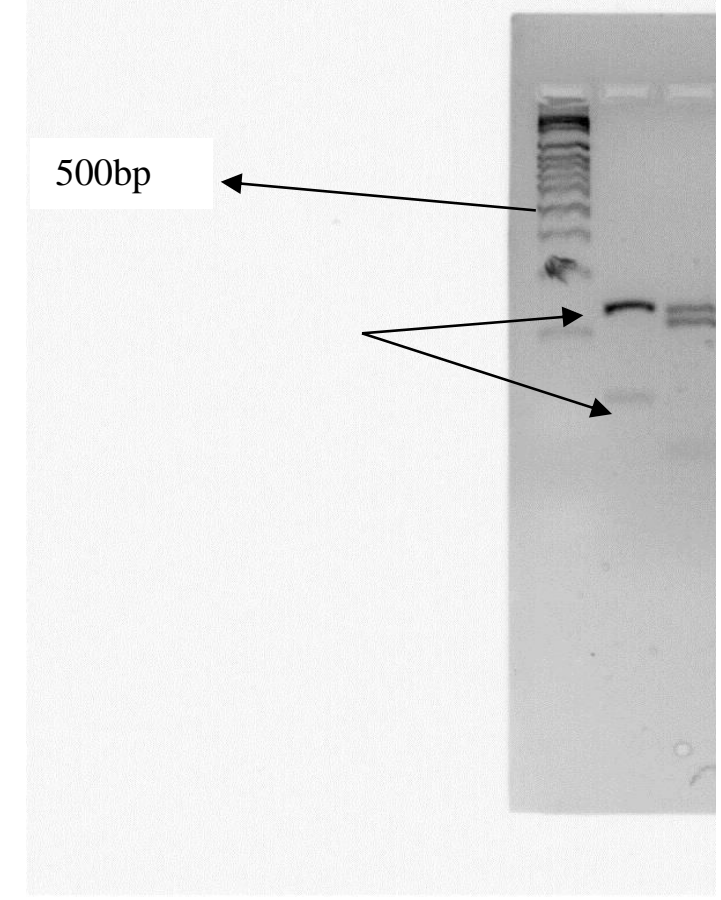

\section{PEMBAHASAN}

Hasil amplifikasi PCR berada pada band 137bp. Produk PCR dianalisa dengan menggunakan tekhnik RFLP dengan menggunakan enzim restriksi $P v u$ II (Thermo scientific $\left.{ }^{\circledR}\right)$, lalu dianalisa dengan elektroforesis gel agarosa $2 \%$ sehingga ditemukan beberapa variasi polimorfisme gen MMP-12 pada penderita PPOK sebagai berikut; Homozigot AA (137bp), Heterozigot AG (, 119bp). Penelitian ini sejalan dengan penelitian (6) setelah analisa RFLP ditemukan beberapa variasi gen MMP-12 pada populasi di Cina. (AA: 137bp, AG: 119bp, GG: 18bp). Penelitian yang dilakukan di Brazilia pada etnis Caucasian, dari 91 orang homozygote AA, sebanyak 84 orang, AG sebanyak 26 orang dan GG hanya 1 orang (7). Demikian juga penelitian yang dilakukan di Boston Amerika serikat, bahwa heterizygot GG lebih sedikit ditemukan, hal ini mungkin terkait etnis Caucasian. ${ }^{(8)}$

\section{KESIMPULAN}

Varian gen pada polimorfisme MMP-12 pada penderita PPOK secara mayoritas adalah genotip AA, dan genotip GG tidak ditemukan, hal ini terkait etnis dan sampel yang terlalu sedikit.

\section{DAFTAR PUSTAKA}

1. Ishii, T., Matsuse, T., Teramoto, S., Matsui, H., Miyao, M., Hosoi, T., Takahashi, H., Fukuchi, Y., dan Ouchi, Y.. Glutathione S-transferase P1 (GSTP1) Polymorphism in Patients with Chronic Obstructive Pulmonary Disease. Thorax, 2006 Volume 54:693-696.

2. Kumar, V., Cotran, I 137bp ins, S.L. Buku Ajar Patologi. V, '. Jakarta, Penerbit Buku Kedokteran ·nก4 75-79

3. Depkes RI. 2007. Sur 119bp Ekonomi Nasional (SUSENAS). Kesehatan Indonesia

4. De Souza, A.P., dan Line, S.R.P.. The Biology of matrix Metalloproteinases. Rev. FOB, 2002 Volume 10, Nomor 1: 1-6.

5. Haq, I., Chappel, S., Johnson, S.R., Lotya, J., Daly, L., Morgan, K., Guetta-Baranes, T., Roca, J., Rabinovich, R., Millar, A.B., Donnelly, S.C., Keatings, V., MacNee, W., Stolk, J., Hiemstra, P.S., Miniati, M., Monti, S., O’Connor, C.M., dan Kalsheker, N.. Association of MMP-12 Polymorphisms with Severe and Very Severe COPD: A Case Control Study of MMPs-1, 9 and 12 in a European Population. BMC Medical Genetics, 2010 Volume 11, Nomor 7: 1-11.

6. Li, W., Jin, X., Zhou, Y., Zhu, M., Lin, X.F., Hu, X., Wang, W., Wang, F., dan Jin, G... Lack of Independent Relationship between The MMP-12 Gene Polymorphism and Carotid Plaque Susceptibility in The Chinese Han Population. Vascular Medicine, 2012Volume 17, Nomor 5: 310-316

7. Schirmer, H., da Silva, L.B., Teixeira, P.J.Z., Moreira, J.S., Moreira A.L.S., dan Simon, D.. Matrix Metalloproteinase Gene Polymorphisms: Lack of Association With Chronic Pulmonary Disease in a Brazilian Population. Genetic and Molecular Research: 2009 Volume 8: 1030-1031.

8. Hunninghake, G.M., Cho, M.H., Tesfaigzi, Y., Soto-Quiros, M.E., Avila, L., Lasky-Su, J., Stidley, C., Melen E., Soderhall, C., Hallberg, J., Kull, I., Kere, J., Svartengren, M., Pershagen, G., Wickman, M., Lange, C., Demeo, D.L., Hersh, C.P, Klanderman, B.J., Raby, B.A., Sparrow, D., Shapiro, S.D., 
Silverman, E.K., Litonjua, A.A., Weiss, S.T., dan Celedon, J.C. MMP12, Lung Function, and COPD in High-Risk Population. The New England Journal of Medicine: 2009, 2, 8. 